International Journal of Current Advanced Research

ISSN: O: 2319-6475, ISSN: P: 2319 - 6505, Impact Factor: SJIF: 5.995

Available Online at www.journalijcar.org

Volume 6; Issue 4; April 2017; Page No. 3346-3348

DOI: http://dx.doi.org/10.24327/ijcar.2017.3348.0268

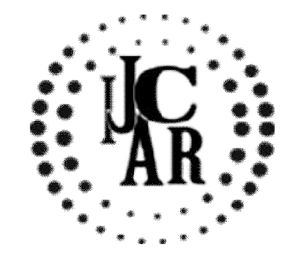

Research Article

\title{
COMPARATIVE ANALYSIS OF RESISTANCE IN SIGHTED AND VISUALLY IMPAIRED PEOPLE
}

\section{Olga Savina and Olga Kvasova}

Psychological Helping and Resocialisation Department, Moscow State University.

\begin{tabular}{|c|c|}
\hline 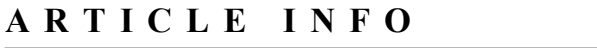 & A B S T R A C T \\
\hline $\begin{array}{l}\text { Article History: } \\
\text { Received } 23^{\text {rd }} \text { January, } 2017 \\
\text { Received in revised form } 10^{\text {th }} \text { February, } 2017 \\
\text { Accepted } 22^{\text {nd }} \text { March, } 2017 \\
\text { Published online } 28^{\text {th }} \text { April, } 2017\end{array}$ & $\begin{array}{l}\text { In the present study the influence of a personality meaning work on the successful coping } \\
\text { with traumatic experience is examined. In personality and trauma research aroused the } \\
\text { concepts: resilience, hardiness, coping, overcoming characterizing person's ability to resist, } \\
\text { withstand stress factors, crisis, extremities -the situation in which people are not only } \\
\text { injured, suffering, but also solves life problems: not only adapt, but take courage to } \\
\text { overcome adversities, be capable for loving and working, constructing, and grow } \\
\text { Theoretical basis of this study is understanding of resilience (Maddi, 2013), the provisions } \\
\text { of meaning activity- approach, focusing on positive aspects of extreme situation and } \\
\text { meaning constructive personality work with stresstrauma experience (Magomed-Eminov, } \\
\text { 2009).. The study was aimed at identifying resistance in extreme situations by the } \\
\text { comparative analysis of stories by sighted people and visually impaired people with its } \\
\text { various etiologies (blind from birth and have lost their vision due to injury). } \\
\text { The assumption that there were differences in manifestation of resistance in people with } \\
\text { visual impairment (congenital or acquired as a result of injury) was tested, The data } \\
\text { provided additional insight into the resources and areas of personality work in the visually } \\
\text { impaired - seeking ways of coping with it and fulfill personality work which actually } \\
\text { makes it possible to transform negative resources into positive outcome of the disaster on } \\
\text { the provisions of meaning activity- approach. }\end{array}$ \\
\hline
\end{tabular}

Copyright $(2017$ Olga Savina and Olga Kvasova. This is an open access article distributed under the Creative Commons Attribution License, which permits unrestricted use, distribution, and reproduction in any medium, provided the original work is properly cited.

\section{INTRODUCTION}

Threat to life becomes non-specific feature of modern life. In modern psychology, attempts are being made to overcome limitations of biological \ medical approach to stress and trauma, to consider extremality not only negatively (Lazarus and Folkman, 1984) but also from a holistic view of personality characteristics responsible for successful adaptation and coping with life adversities (MagomedEminov, 2013). It is important to find out what hardiness is from the position of understanding man as a living selfdeveloping (and self-organizing) system - a system capable of "producing" vitality and inner harmony that are subjectively perceived as well-being. Disturbances and loss of vision is life situation in which a person is not only traumatized, experiences suffering, but also adapts, manifests courage, overcomes negative factors, actively lives, loves, works, grows personally.

Studying the personality in particularly difficult and extreme life situations led to the identification of phenomena that

*Corresponding author: Olga Savina

Psychological Helping and Resocialisation Department, Moscow State University broad sense. These include concepts such as resilience, coping, hardiness (Aldwin, 1994; Allred, Smith, 2011; Maddi, 2013). The term "hardiness" reflects psychological vitality, and is also an indicator of a person's mental health (Kobasa, Maddi, 2012). The personal quality of "hardiness" emphasizes attitudes that motivate a person to transform the stressful life events that she encounters every day, and those that are near extremal and extreme (Contrada, Baum, 2012). According to studies (Solcova, Tomanek, 1994), dealing with the relationship between "hardiness" and stress in conditions that induce anxiety, those with less anxiety and high rates of hardiness demonstrated weaker physiological responses when confronted with stress. The components of hardness (involvement and control) have been predictive of mental health. Involvement increased mental health, reducing threat evaluation and the use of emotion-focused coping strategies, increasing the role of secondary reevaluation of events. The severity of control had a positive effect on mental health, led to reduction in the evaluation of threat of the event, helped to reevaluate the event and encouraged the use of coping strategies aimed at solving problems and seeking support (Stangor, 2012). Rush and all. (Rush and all, 1995) considered psychological stability (flexibility) in terms of 
resistance to pressure for change. It has been confirmed that pressure to change is associated with feelings of tension, subsequent dissatisfaction and the desire to avoid change. The psychological quality of "hardiness" has a direct negative impact on stress and a direct positive on the feeling of satisfaction. Maddy et al. consider the role of the early past in "hardiness", and this personal quality is seen in studies as an important buffer in the transition of stress to illness (Kobasa, Maddi, 2012), a high role in increasing the indicators of the factors such as compensating family standards and selfperception. The quality of "hardiness" (self-perception, containing a sense of inclusion, control, challenge and trust) according to Evans and all. (Ed.Contrada, Baum, 2012).) is an integral part of the feeling of life fullness and quality of life. The basis for many studies of blind people psychology is the concept of A. Adler (Adler, 2011): normal development may be threatened by organic insufficiency. Thus, visual sensory deprivation is the primary cause of the peculiarities of the inner mental world of visually impaired people (Silkin, 2012). The inadequacy of organs becomes a stimulus for mental development and personality growth. So, trying to overcome the limitations and internal conflicts caused by blindness, a person exerts maximum efforts to prove to himself and others by his own achievements that he is no worse than other healthy people, that he also has the right to be a full member of society, that he too can be useful for other people. The theoretical basis was the understanding of the structure of viability, the notion of individual resources as a self-organizing system, the position of the activity-semantic approach (Magomed-Eminov, 2013), emphasizing the positive aspects of extremism and the semantic work of the individual with traumatic experiences.

\section{MATERIALS AND METHODS}

In the study aimed at identifying resistance in extreme situations comparative analysis of the discourses of people with normal vision and people with their violations of various etiologies (blind from birth and lost sight due to trauma) was used. The paper tested the hypothesis of differences in the manifestation of resistance in people with visual impairment (congenital and acquired as a result of trauma) and sighted with the help of the "Test of hardiness" (Maddi, 2013) and developed interview about difficult life situation (written story about experiencing and overcoming a crisis situation with the use of subsequent qualitative analysis.) The empirical sample (90 people) consisted of three groups, equal in number of respondents: 1) sighted people: 18 women and 12 men, (22 to 45 years old), average age 32.4 years, 2) lost sight due to trauma, 13 men and 17 women, (18-44 years old-, average age 35.2 years), the time of injury is from 5 to 12 years ago, causes of vision loss: a) accident (12 people), b) severe stress, causing visual pathology (5 people); c) occurrence or sharp exacerbation of other somatic diseases that caused loss of vision (10 people); d) medical error (3 people); 3) with congenital visual impairment: 17 women and 13 men, (18 to 45 years old, average age 33.7 years). The study was conducted in the conditions of a psychological laboratory using electronic forms.

\section{RESULTS}

Data have been obtained that in people with congenital visual impairment in comparison with sighted and visually impaired as a result of injury, the following indicators were higher: a general level of Hardiness (respectively: $\overline{\mathrm{x}} 3=90,0 ; \overline{\mathrm{x}} 1=$ 81,$3 ; \bar{x} 2=74,6$ ), Control (respectively: $\bar{x} 3=35,7 ; \bar{x} 1=$ 30,$3 ; \bar{x} 2=26,2$ ) and Risk acceptance (respectively: $\bar{x} 3=$ $19,3 ; \overline{\mathrm{x}} 1=14,4 ; \overline{\mathrm{x}} 2=14,8)$.

Table 1 Descriptive statistics on Test of hardiness results

\begin{tabular}{|c|c|c|c|}
\hline & $\begin{array}{c}\text { Group } 1 \\
\text { Sighted } \\
\text { people }\end{array}$ & $\begin{array}{c}\text { Group 2 } \\
\text { Lost sight } \\
\text { due to } \\
\text { trauma }\end{array}$ & $\begin{array}{c}\text { Group 3 } \\
\text { Congenital } \\
\text { visual } \\
\text { impairment }\end{array}$ \\
\hline \multicolumn{4}{|c|}{ Hardiness } \\
\hline $\mathrm{X}$ & 81,33 & 74,6 & 90,03 \\
\hline MIN & 62 & 56 & 64 \\
\hline MAX & 98 & 99 & 110 \\
\hline t-Student Groups $1 / 2$ & \multirow{2}{*}{\multicolumn{2}{|c|}{2.3}} & \\
\hline t-StudentGroups $1 / 3$ & & & \\
\hline \multicolumn{4}{|c|}{ Involvement } \\
\hline $\mathrm{X}$ & 36.6 & 33.5 & 35.6 \\
\hline MIN & 24 & 21 & 23 \\
\hline MAX & 49 & 45 & 45 \\
\hline t-Student Groups $1 / 2$ & \multirow{2}{*}{\multicolumn{2}{|c|}{1.9}} & \\
\hline t-StudentGroups $1 / 3$ & & & \\
\hline \multicolumn{4}{|c|}{ Control } \\
\hline $\mathrm{x}$ & 30.3 & 26.2 & 35.66 \\
\hline MIN & 16 & 15 & 23 \\
\hline MAX & 45 & 42 & 48 \\
\hline t-Student Groups $1 / 2$ & \multirow{2}{*}{\multicolumn{2}{|c|}{2}} & \\
\hline t-StudentGroups $1 / 3$ & & & \\
\hline \multicolumn{4}{|c|}{ risk\Acceptance } \\
\hline $\mathrm{x}$ & 14.4 & 14.8 & 19.3 \\
\hline MIN & 7 & 9 & 12 \\
\hline MAX & 22 & 23 & 25 \\
\hline t-Student Groups $1 / 2$ & \multirow{2}{*}{\multicolumn{2}{|c|}{0,4}} & \\
\hline t-StudentGroups $1 / 3$ & & & \\
\hline
\end{tabular}

Significance of differences at $\mathrm{p}<0.05$

A comparative analysis using the t-Student test showed statistically significant differences in these parameters between people with congenital visual impairment and two other groups $(\mathrm{p}<0.05)$, the differences between people who lost sight due to trauma and those who are sighted are not significant.

\section{DISCUSSION}

A qualitative analysis of the stories about the experiences of crisis situations and the evaluation of the consequences showed that in the situation of traumatic loss of sight, the fact of blindness becomes one of the central points in life experience, and the possibility of its positive transformation and integration becomes difficult. Subjects from this group indicated that the loss of vision completely changed their life, led to the loss of the former life meanings and purposes, the need to search for new ones. People with congenital visual impairments show similarities to those who are sighted in distinguishing the types of crisis situations (loss of a loved one, family breakdown, etc.), but in describing the consequences, they evaluate their experience and their own efforts to overcome difficulties more positively. For this group, the situation of visual impairment is the source of the formation of a high level of resistance, which allows to act constructively in stressful situations. 


\section{CONCLUSIONS}

The received data deepen understanding of resources and directions of personality work in people with visual impairments that will allow to individualize rendering of psychological help. As a prospect of research, it is possible to distinguish a more detailed study of the prerequisites for the formation of a high level of resistance in people with congenital visual impairments. The resource of forming a high level of durability is not the very fact of visual impairment, but the methods coping, direction and quality of constrictive personality work with life experience to keep and form positive integrative identity and to transform negative resources into positive personal outcomes

\section{References}

Adler A. Theory and practice of individual psychology / M., 240 p.2011

Aldwin C. M. Stress, coping, and development. Second Edition: An Integrative Perspective. New York: The Guilford Press. 2009

Allred K.D., Smith T.W. The Hardy Personality: Cognitive and Physiological Responses to Evaluative Threat. // Journal of Personality and Social Psychology, 2009, Vol. 56, No. 2, 257-266
Kobasa S.C., Maddi S. R., Kahn S. Hardiness and health: A prospective study. // Journal of Personality and Social Psychology -PSP, 2012 vol. 42, no. 1, pp. 168-177,

Lazarus, R. S., \& Folkman, S. Stress, appraisal, and coping. New York: Springer. 1984.

Maddi S. R. Personal Hardiness as the Basis for Resilience. // Springer Briefs in Psychology, 2013

Magomed-Eminov M.Sh. Ontological conceptualization of the extremality phenomenon // Vestnik MGU. Series 14.Psychology. -.2014 - № 3. - P.79-91.

Magomed-Eminov M.Sh. Phenomenon of Extremality // Bulletin of St. Petersburg State University. Series 12. Psychology. Sociology. Pedagogy. - 2010. - №1. P.28-38.

Rush, M. C., Schoael, W.A., and Barnard, S. M. Psychological resiliency in the public sector: "Hardiness" and pressure for change. Journal of Vocational Behavior. Feb 46(1), 1995. P. 17-39.

Silkin L.N. Diagnosis and psychotherapy of visually impaired people, M, 2012

Solcova, I, and Tomanek, P. Daily stress coping strategies: An effect of Hardiness. Studia Psychologica, 1994, v36 (n5) :390-392.

Stangor C. Beginning Psychology. Chapter 10.2. Stress: The Unseen Killer // http://2012 books.lardbucket.org/books/beginning-psychology.

The Handbook of Stress Science: Biology, Psychology and Health. Edited by Richard J. Contrada and Andrew Baum. Springer, New York, 2011. P. 676.

\section{How to cite this article:}

Olga Savina and Olga Kvasova (2017) ' Comparative Analysis of Resistance in Sighted and Visually Impaired People', International Journal of Current Advanced Research, 06(04), pp. 3346-3348.

DOI: http://dx.doi.org/10.24327/ijcar.2017.3348.0268 